\title{
Legitimacy and the Cost of Government
}

\author{
Niclas Berggren, Christian Bjørnskov and \\ David Lipka
}




\title{
Legitimacy and the Cost of Government ${ }^{\S}$
}

\author{
Niclas Berggren, Christian Bjørnskov and David Lipka*
}

\begin{abstract}
While previous research documents a negative relationship between government size and economic growth, suggesting an economic cost of big government, a given government size generally affects growth differently in different countries. As a possible explanation of this differential effect, we explore whether perceived government legitimacy (measured by satisfaction with the way democracy works) influences how a certain government size affects growth. On the positive side, a legitimate government may “get away” with being big since legitimacy can affect people’s behavioral response to, and therefore the economic growth cost of, taxation and government expenditures. On the negative side, legitimacy may make voters less prone to acquire information, which in turn facilitates interest-group oriented or populist policies that harm growth. A panel-data analysis of up to 30 developed countries, in which two different measures of the size of government are interacted with government legitimacy, reveals that legitimacy exacerbates a negative growth effect of government size in the long run. This could be interpreted as governments taking advantage of legitimacy in order to secure short-term support at a long-term cost to the economy.
\end{abstract}

Keywords Legitimacy • Economic growth • Size of government • Confidence • Trust

JEL Classification $\mathrm{E} 62 \cdot \mathrm{H} 11 \cdot \mathrm{H} 20 \cdot \mathrm{O} 43 \cdot \mathrm{Z} 13$

\footnotetext{
$\S$ The authors wish to thank Andreas Bergh, Enrico Colombatto, Jerg Gutmann, Pelin Ayan Musil, Christoph Schenke, participants at the Institute for Research in Economic and Fiscal Issues (IREF) and Anglo American University workshop in Prague and participants at the Public Choice Society Meetings in Charleston for useful comments and suggestions, and the Institute for Research in Economic and Fiscal Issues (IREF) (all), the Swedish Research Council (Berggren) and Johan \& Jakob Söderbergs stiftelse (Berggren) for financial support. Rasmus Rødby Kristiansen and Aleš Rod provided excellent research assistance.

${ }^{*}$ N. Berggren (corresponding author), Research Institute of Industrial Economics (IFN), P.O. Box 55665, SE10215 Stockholm, Sweden; and Department of Institutional Economics, University of Economics, Prague, Czech Republic. Phone: +4686654520. Fax: +4685544599. E-mail: niclas.berggren@ifn.se.

C. Bjørnskov, Department of Economics and Business, Aarhus University, Fuglesangs Allé 4, DK-8210 Aarhus V, Denmark. E-mail: ChBj@asb.dk.

D. Lipka, School of International Relations and Diplomacy, Anglo American University, Lázeňská 4, 11800 Prague; and Jan Evangelista Purkyne University, Pasteurova 1, 40096 Ústí nad Labem, Czech Republic. E-mail: david.lipka@aauni.edu.
} 


\section{Introduction}

For a long time, government has grown in most countries. For example, looking at total tax revenues as a share of GDP, OECD governments taken together grew from 25.5\% in 1965 to $33.8 \%$ in 2010 (OECD 2013). In many countries in Europe, the figure is at present above $40 \%$. This makes it important to study the consequences of government size for the overall economy. Bergh and Henrekson (2011) present a survey of the literature that looks at the growth effects, and they conclude that most recent studies report a negative relationship. Even though this is a general pattern, they also note that it is not impossible to grow fast with a big government, and suggest that other factors that mitigate or undo the negative incentive effects of high taxes - either institutions, policies or social trust - may be present in certain countries. We wish to propose another "social” factor as being potentially relevant: the legitimacy of government. There are indications from previous studies that legitimacy affects the behavior of both economic and political actors, and as such, we expect it to matter also for the issue at hand. For the first time in the literature, we present an empirical investigation of whether this factor is de facto relevant. ${ }^{1}$

Why would we, first of all, expect the size of government to affect economic growth? According to the neoclassical growth model, the size of government does not affect growth, except in the presence of major market failures or, possibly, in a transitory stage, moving towards the steady-state growth path. In this setting, fiscal policy only affects output levels, while growth rates are exogenously determined by population growth and technological change. However, in an endogenous-growth framework, the size of government can have large effects on growth rates (King and Rebelo 1990; Kneller et al. 1999). The reason is that taxes and expenditures can influence investment in and utilization of physical and human capital. However, it is by no means theoretically clear whether the influence is positive or negative - not least, it depends on how distortionary taxes are and how expenditures affect incentives for productive behavior.

Why would we, secondly, expect government legitimacy to affect the sign and size of the growth effects of government size? Arguments exist for both a positive and negative influence. On the positive side, the basic idea is that when economic actors decide how much to invest in and how to use their physical and human capital, they not only take tax rates and government benefits into account - they are also influenced by how they perceive government

\footnotetext{
${ }^{1}$ Note that we do not study how legitimacy affects government size or vice versa.
} 
to work in relation to what they regard as evaluative criteria. These criteria typically differ between individuals but reasonably entail goals such as the fulfillment of desired outcomes, transparency, honesty, non-corruption, adherence to the rule of law and keeping made promises. To take one example, a given tax rate on labor income can then have different effects on growth in a setting where economic actors overall find government legitimate compared to a setting where they find the degree of legitimacy low. In the former case, investment in education and work effort can be high even with high tax rates; and in that case resources devoted to avoiding taxes and to lobbying the government can be used for productive purposes instead, with positive growth effects.

On the negative side, however, political leaders may exploit the legitimacy awarded to the political system in ways that harm growth. Taxes and expenditures may be chosen to solidify political positions rather than aim at high growth, and policies geared towards interest groups or populism may come to dominate more easily if voters deem the government legitimate. Many voters are likely to remain rationally ignorant, and more so if they to some extent believe that politicians either have the right motives or that policies will benefit them (cf. Downs 1957; Nannestad and Paldam 1994; Caplan 2007). It follows that if voters remain politically ignorant - if they do not know much about the growth effects of policies and if legitimacy makes them less prone to invest time and effort into the acquisition of more information - politicians are in a better position to take advantage of legitimacy to further their own interests.

We develop these ideas further below and test the relationship empirically, using annual panel data, which allow us to closely follow within-country changes in legitimacy. We measure legitimacy as a compound measure of satisfaction with democracy and confidence in parliament and political parties. This approach allows us to build an annual panel of comparable data on legitimacy and growth. We apply an error-correction model to these data in order to be able to separate pure business cycles from longer-run growth patterns.

Our empirical analysis shows that the negative effect of government size on growth seems to become larger the more legitimate the government is perceived to be. The negative aspects of legitimacy hence dominate when government is of a certain size. This result is robust to removing post-communist countries and to including measures of actual institutional quality. We also find that legitimacy in itself is beneficial for growth if government size is smaller than 25 percent in the case of government consumption and smaller than 43 percent in the case of taxation. Hence, it seems important to evaluate the growth effects of legitimacy and government size in the interaction framework that we try to provide. The most promising 
combination from a growth perspective seems to be to have a low- to medium-sized government with high legitimacy; and when government is big, less legitimacy would increase growth. However, this is not to say that it is easy in practice to either change the size of government or bring about more or less legitimacy.

The paper is organized as follows. After a presentation of how the study relates to the previous literature and of theoretical preliminaries (Section 2), we describe our data and empirical strategy (Section 3). After reporting the empirical results (Section 4), concluding remarks close the paper (Section 5).

\section{Previous literature and theoretical preliminaries}

The purpose of this section is to provide a clarification of what we mean by the concept of legitimacy and a theoretical outline of how we expect legitimacy to influence the effect of government size on growth. Yet, before doing so, we provide a short summary of the claims in related literature.

\subsection{Previous literature}

Our paper relates to previous studies on the growth effects of government size and to earlier analyses of the consequences of government legitimacy (sometimes conceptualized as trust or confidence in government). As indicated, Bergh and Henrekson (2011) provide a review of the former issue on the basis of seven recent studies using panel data from developed countries, and they find consistent indications of a generally negative association (as reported in their Table 2). ${ }^{2}$ An increase in government size by 10 percentage points (where size is measured either by total taxes/GDP or total government expenditures/GDP) is in most cases related to a reduction of the annual growth rate of real GDP per capita by 0.5 to 1 percentage points. $^{3}$

\footnotetext{
${ }^{2}$ For some other studies, see, e.g., Mendoza et al. (1997), Bleaney et al. (2001) and Facchini and Melki (2013).

${ }^{3}$ Nijkamp and Poot (2004) provide an earlier metaanalysis of 93 published studies and find indications of a positive but weak effect on growth of expenditures on education and infrastructure, as well as support for the hypothesis that higher taxes lower growth.
} 
Bergh and Karlsson (2010) use the Bayesian Averaging of Classical Estimates method to see whether the negative association between taxes/GDP and growth is robust with regard to the model specification. They find that it (unlike most other variables tested) is. They find evidence of countries with big government successfully using economic openness and certain economic policies to mitigate the negative growth effect. Some have also looked at disaggregated tax and expenditure data. For example, Romero-Ávila and Strauch (2008) find negative growth effects of direct taxation but no effects from indirect taxation or contributions to the social-security system. Furthermore, they find that government consumption and transfers have a negative, and government investment a positive, effect. In contrast, Alfonso and Furceri (2010) present negative findings for indirect taxes and, on the expenditure side, for government consumption, subsidies and social contributions. Clearly, different types of taxes and expenditures can have different effects, in different times and different places, but the general pattern is a negative or no, rather than a positive, relationship. In line with our approach, Oto-Parealías and Romero-Ávila (2013) study whether government size (primarily measured as the general government consumption as a share of GDP) affects growth differentially depending on the quality of the public sector (in particular its bureaucracy). They find indications of a negative effect in cases when bureaucratic quality is low and no statistically significant effect when that quality is high.

When it comes to empirical studies on government legitimacy, Weede (1996) recognizes that legitimacy is a form of social capital that reduces transactions costs, which is efficiency-enhancing, but he warns that politicians may try to achieve legitimacy by interfering with the way the market works, which could lower growth rates. Still, he also finds indications of a positive relationship between legitimacy and growth. Rudolph (2009) presents the idea that trust in government is positively related to support for tax cuts, since they are an instance of government action under risk that should be more acceptable to voters if they believe that the government is trustworthy. He tests it in a U.S. setting and finds that political trust indeed bolsters support for tax cuts, but only among liberal voters. However, Rudolph and Evans (2005) find that political trust is also related to support for higher public spending in the U.S., and more so for conservative voters. It thus seems as if voters are more prone to support higher government expenditures when they regard government as trustworthy. Yamamura (2012) studies Japan and finds that people are more likely to favor income redistribution and to perceive the tax burden as low when trust in government is high in the area where they live. The results apply to high-income earners only. The latter result is 
especially interesting for our purposes, since it implies a "fiscal-illusion" effect that can countervail the inefficiency of high taxes.

Against this background, we now turn to our own analysis. Since the literature as surveyed is based on a rather diverse collection of concepts, we first define the concepts before discussing the theoretical possibilities.

\subsection{The concept of legitimacy}

Lipset (1959: 85), correctly in our view, describes legitimacy as an affective and evaluative concept. More precisely, we follow Levi et al. (2009: 354) in viewing legitimacy as an attitude towards the government that “... derives from the beliefs citizens hold about the normative appropriateness of government structures, officials, and processes”. If government structures, officials and processes are regarded as normatively appropriate, this implies the view that "rules and regulations are entitled to be obeyed by virtue of who made the decision or how it was made”. Without government legitimacy, any particular regime will probably not be able to stay in power for very long, unless it uses force (Levi et al. 2009: 377).

There is one value-based and one behavioral part to legitimacy. The former is the normative attitude, the latter the way this attitudes manifests itself in actual behavior. People who hold that government is legitimate also tend to follow its decisions. Again following Levi et al. (2009), the determinants of legitimacy are of two kinds: the trustworthiness of government and procedural justice. The former stems from three factors: government performance, leadership motivations and administrative competence. If, from the point of view of the citizen, government outcomes are pleasing; if politicians and bureaucrats are thought to be motivated by a concern for the interests of citizens in general; and if they are considered skillful, then government is considered trustworthy, which creates legitimacy. So does procedural justice: that there is an effective rule of law in place (that also encompasses the rulers). If, on the contrary, there is discretion of a non-general kind, maybe connected to corruption, then citizens will see political decision-making as being in violation of procedural justice, which will reduce, and possibly completely eliminate, legitimacy. ${ }^{4}$

\footnotetext{
${ }^{4}$ A similar understanding of legitimacy is developed by Beetham (1993), who lists three criteria of legitimacy: whether power is acquired and exercised according to established rules; whether the rules are justifiable by reference to shared beliefs; and whether people consent with the political system. Cf. Colombatto (2014), who is wary of consequentialist explanations of legitimacy and sees it as being a matter of subjective value judgment which originates from the individual's assessment of the prevailing rules of the game in the light of his own
} 


\subsection{Theoretical preliminaries}

We now wish to explore theoretically how government legitimacy affects the causal link between government size and economic growth. We posit that the effects can be both positive and negative, in the sense that an increase in legitimacy can either increase or decrease the growth effect of a given government size.

The size of government influences economic growth through the way it affects economic agents. For example, taxes affect the economic decisions that are being made, both in deciding how much to work and how much to invest in physical and human capital. Likewise, government expenditures provide people with resources, directly or indirectly (through government programs), that will shape their decisions regarding such things as work effort and education; also, productivity can be directly affected by government providing infrastructure etc. All of these effects can influence growth rates.

Let us now introduce government legitimacy. As we see it, legitimacy influences the growth effect of government size through the behavior of political decision-makers and/or through the behavior of economic agents. A given government size affects growth differently depending on how legitimate people think the government is. We suggest five mechanisms that can assist in explaining this. The first three proposed mechanisms work through the behavior of economic agents and then also through the policy responses this behavior gives rise to (with positive or negative effects on our variable of interest); the last two mechanisms only work through the behavior of economic agents (with positive effects on our variable of interest).

The first mechanism. Legitimacy makes people more willing to obey and defer to the government. This in turn affects how given government resources are used. Governments with low legitimacy have less obedient and deferent citizens and must devote more resources to the enforcement of its policies and to maintaining order (Gilley 2006: 499; Tyler 2006a,b; Levi et al. 2009: 354-356). This includes higher costs for collecting taxes (Lieberman 2002: 94), since tax compliance is weaker. High legitimacy enables government, at any given size, to use resources freed up by obedient citizens on higher expenditures (such as infrastructure, education, subsidies or benefits) and/or lower taxes, without sacrificing the de facto quality of the legal institutions. As for how this mechanism affects the relationship between government 
size and growth, the sign is unclear, as it depends on which expenditures and taxes are changed. $^{5}$

The second mechanism. Legitimacy affects people's attitudes to policies with growth effects, which in turn leads political decision-makers to change polices in line with these attitudes. It has been shown that certain policy changes and reforms are easier and less costly to undertake when government is considered legitimate - for example, support for tax cuts and for increased expenditures (Rudolph and Evans 2005; Rudolph 2009). As in the case of the first mechanism above, this suggests that legitimacy is related to the composition of the government budget, which affects growth (but again, the sign is unclear). Moreover, if legitimacy is low, we suggest this causes people to distrust the government's willingness and ability to alleviate various economic problems, which leads to a lower demand for regulation (Pitlik and Kouba 2014). To the extent that (potential) regulation is of a growth-hampering kind, this would imply that legitimacy affects the growth effect of government size negatively. ${ }^{6}$

The third mechanism. In a political context where legitimacy is high, political decision-makers (may, at least, think that they) have more leeway to do what they want without suffering popular discontent. As noted by Tyler (2006a: 381), “legitimacy provides a 'reservoir of support' for institutions and authorities, something besides immediate selfinterest, which shapes reactions to their policies ...”. Politicians can, in a sense, "free-ride” on the legitimacy of the system, where legitimacy serves as a kind of "filter" which downplays the importance of certain negative outcomes such as lower growth. The way it does so is by reducing the willingness of voters to acquire information about the growth effects of policies (from a starting point where voters are not particularly knowledgeable about such effects; cf. Caplan 2007). There are at least two ways in which this can come about. In the first case, politicians enter into exchange with interest groups, in which the latter obtain favors, in the form of changes to the tax or expenditure structure, that reduce growth and in which politicians get various types of material support. In this case, politicians act against (both the short- and the long-term) interest of voters - and they feel more confident in doing so the higher the degree of government legitimacy, as voters' incentives to find out about details of

\footnotetext{
${ }^{5}$ As Bergh and Henrekson (2011: 873) note: "There are also strong theoretical reasons to expect different types of taxes and expenditures to have differential growth effects”.

${ }^{6}$ Studies show that social trust is negatively related to a demand for and a supply of regulations (Aghion et al. 2010; Bergh and Bjørnskov 2011; Pinotti 2012). However, Pitlik and Kouba (2014) show that people who trust government (relative to companies) favor interventionism even if their social trust is strong.
} 
economic-policy effects become weaker with legitimacy. This is somewhat in line with what Levi et al. (2009: 355) imply when noting that "[l]egitimacy does not signify that power will be used to promote the good of the nation or of humanity”. As such, a sufficient degree of legitimacy may provide additional political room for maneuvering and allow easier implementation of special interest expenditures or programs. In the second case, the exchange is with voters instead, and the purpose is to get more votes (cf. Weede, 1996). This is a case of politicians acting in the short-term but against the long-term interests of voters in a populist way - and they are, again, more confident in doing so the more legitimacy there is. The idea is that voters are quite aware of distributional policy initiatives that affect their disposable incomes here and now but not very well informed about the importance of (long-term) growth. And the more legitimate government is thought to be, the less voters are interested in investing in new information (especially about complex matters as growth). As stated by Caplan and Stringham (2005: 89), "If voters have blind faith in their leaders, wasteful programs multiply like rabbits.” To sum up, both of these alternatives (interest-group influence and populism) point at a negative effect on the growth effect of government size from legitimacy.

This brings us to the two last mechanisms, which only involve the behavior of economic agents and no subsequent change in the behavior of political decision-makers.

The fourth mechanism. Legitimacy affects individuals' usage of resources. In the presence of widespread legitimacy, people are less likely to undertake measures to protect their incomes, either in the form of private actions, such as tax evasion (Richardson 2008), which affects the size of the shadow economy, or in the form of public ones, such as engaging in rent-seeking (Murphy et al. 1993; Halla and Schneider 2014). Resources that could be used to satisfy individual ends are no longer diverted into unproductive activities. The effect on growth should be positive, since people will tend to use their means to consumption or investment instead.

The fifth mechanism. Legitimacy affects how individuals respond to taxes, by giving rise to the "psychological" effect of regarding a given tax level as less burdensome. If one finds government legitimate, one is likely to have confidence in and approve of the way that (one perceives) government uses tax revenue, which provides a motivation to work and invest more at given tax rates compared to a situation where government legitimacy is low. In other words, legitimacy may reduce the negative labor-supply effects of high marginal tax rates and therefore limit the negative growth effects of a given, heavy tax burden. This could be the result of a conscious evaluation or a kind of fiscal-illusion effect (Buchanan 1967); in both 
cases, people behave as if the tax rates were lower. This, in turn, then tends to reduce the distortive effects of taxation and can induce higher growth at a given tax-rate level.

The five mechanisms are summarized briefly in Table 1.

Table 1 How legitimacy affects economic and political behavior and growth

\begin{tabular}{|c|c|c|c|}
\hline & Economic behavior & Political behavior & $\begin{array}{l}\text { Growth effect of } \\
\text { the size of } \\
\text { government }\end{array}$ \\
\hline \multirow[t]{3}{*}{$\begin{array}{l}\text { Legitimacy } \\
\text { affects } \\
\text { economic } \\
\text { and } \\
\text { political } \\
\text { behavior }\end{array}$} & $\begin{array}{l}\text { Mechanism 1. People become more } \\
\text { deferent and obedient }\end{array}$ & $\begin{array}{l}\text { Less resources devoted to } \\
\text { legal enforcement, e.g., } \\
\text { tax collection }\end{array}$ & $\begin{array}{l}\text { Positive or negative } \\
\text { effect, depending } \\
\text { on what the freed- } \\
\text { up resources are } \\
\text { used for }\end{array}$ \\
\hline & $\begin{array}{l}\text { Mechanism 2. People's attitudes to } \\
\text { policies change }\end{array}$ & $\begin{array}{l}\text { In response to changes in } \\
\text { popular support, policies } \\
\text { with growth effects } \\
\text { (expenditures, taxes and } \\
\text { regulations) are changed }\end{array}$ & $\begin{array}{l}\text { Positive or negative } \\
\text { effect, depending } \\
\text { on how policies } \\
\text { change }\end{array}$ \\
\hline & $\begin{array}{l}\text { Mechanism } 3 \text {. People become less } \\
\text { prone to invest in the costly } \\
\text { acquisition of information about } \\
\text { the long-run growth effects of } \\
\text { policies }\end{array}$ & $\begin{array}{l}\text { Thus, legitimacy enables } \\
\text { politicians to undertake } \\
\text { policies that benefit } \\
\text { interest groups or that are } \\
\text { populist, without a focus } \\
\text { on growth }\end{array}$ & Negative effect \\
\hline \multirow[t]{2}{*}{$\begin{array}{l}\text { Legitimacy } \\
\text { affects } \\
\text { economic } \\
\text { behavior }\end{array}$} & $\begin{array}{l}\text { Mechanism 4. People respect, like } \\
\text { and trust political decision-makers } \\
\text { more, and devote less resources to } \\
\text { unproductive activities such as tax } \\
\text { evasion and shielding from } \\
\text { government }\end{array}$ & - & Positive effect \\
\hline & $\begin{array}{l}\text { Mechanism } 5 \text {. People respect, like } \\
\text { and trust political decision-makers } \\
\text { more, and are therefore more } \\
\text { willing to work and invest at given } \\
\text { tax rates }\end{array}$ & - & Positive effect \\
\hline
\end{tabular}

For these reasons, we believe that legitimacy has the potential to affect how the size of government affects growth - but the sign of the net effect is theoretically unclear. It must be established by means of empirical analysis.

Before turning to the empirics, let us address two possible concerns. The reasoning so far has been conducted on the premise that government size is given, and we have asked how legitimacy then affects the way this size influences growth. However, the effects of legitimacy presented above may also lead to a change in the size of government. If enforcement is less costly, government could retain its size and use the "saving" to change other expenditures or taxes. But it could also forego the "saving" and expand. In a similar 
fashion, if legitimacy shapes policy attitudes, lower taxes and higher spending could (and seem to) follow. Furthermore, if the taxpayers resort less to unproductive activities to protect themselves, their resources will be put to productive use, which can increase the tax base and also tax revenues. And if people regard the taxes paid as less burdensome at some particular because they regard government as legitimate, this could induce government to increase taxes such that the perceived burden is the same as before. Lastly, if people are quite ignorant of the growth-effects of policies, and if legitimacy makes them less prone to acquire costly information, then this suggests that government can respond to interest-group demands or populist groups that ask for more benefits. All this implies that legitimacy may bring about, not only change in the way the present government size relates to growth, but also an increase in government size, which in turn affects (among other things) growth. ${ }^{7}$ Still, in the empirical analysis, the relationships can be analyzed at any given government size, and that is our focus in this paper - the full dynamic aspects are left for future work.

Our second concern is that while we focus on how legitimacy changes the (marginal) impact of government size, all interactions must be interpreted symmetrically. We also need to consider how government size affects the marginal impact of government legitimacy on growth. Some hold that legitimacy is a good in itself, as it reflects the perceived quality of public bureaucracies and institutions. These institutions, in turn, are responsible for implanting and enforcing government policies as well as for enforcing public order and the rule of law. Given the strong evidence of long-run effects of the rule of law and institutional quality, one would expect legitimacy to be positively associated with long-run growth. However, Aidt (2003) argues that strong institutions may be detrimental to development when combined with ill-conceived public policies. As is the case with our third mechanism above, a large public sector is likely to reflect a mass of decisions with low or negative marginal growth benefits. In such cases, a large government might undermine the positive effects of legitimacy per se, by forcing a good public bureaucracy to enforce bad decisions. Eventually, with sufficiently bad institutions, the poor enforcement of bad policies (reflected in low legitimacy) may serve as a buffer against bad consequences of such policies. This suggests that legitimacy might stand in a negative relation to the growth effects of government size: if

\footnotetext{
${ }^{7}$ We have checked whether legitimacy as such directly affects government size, and we found only very weakly significant and quite small effects. Thus, there is no strong relationship between legitimacy and government size in our data, so this potential effect should not confound our other findings.
} 
small government is related to good policies, legitimacy reinforces a positive growth effect; if large government is related to bad policies, legitimacy reinforces a negative growth effect.

\section{Data and empirical strategy}

In order for us to test the diverse implications arising from our theoretical considerations, we must be able to measure both legitimacy and its consequences. In the following, we outline our data, measurement strategy and choice of estimator before we turn to the empirical results.

\subsection{Measuring government legitimacy}

In Section 2.1, we described our understanding of government legitimacy. Measuring it is far from a simple matter (e.g. Chanley et al. 2000; Chang et al. 2006). What is common to all attempts to proxy government legitimacy is a core concept of public confidence in the way the incumbent government, political parties and the political institutions function, whether in terms of outcomes or in terms of procedural justice. Should some or all parts of this system not live up to the expectations of the electorate, a decline of legitimacy ought to be visible in indicators capturing satisfaction with the system, trust or confidence in political institutions, and potentially also as an increase in social unrest.

To an extent, the main aim of this paper restricts the choice of indicator, as no single longer time series exists for any group of countries. For the member states of the European Union, as well as three additional countries covered by the EuroBarometer (2013) in recent years, we instead construct such a time series from a set of variables that are all likely to measure the same underlying concept. The countries included in the EuroBarometer are: Austria, Belgium, Bulgaria, Croatia, Cyprus, the Czech Republic, Denmark, Estonia, Finland, France, Germany, Greece, Hungary, Ireland, Italy, Latvia, Lithuania, Luxembourg, Macedonia, Malta, the Netherlands, Poland, Portugal, Romania, Slovakia, Slovenia, Spain, Sweden, Turkey and the United Kingdom. As such, the sample includes 12 countries with a communist past and 18 countries without. We observe the first countries from 1975 and let our sample end in 2011. 
A main problem is that the EuroBarometer changed its main questionnaire in the mid2000s, such that there is no single proxy of legitimacy available for all years. However, a set of questions arguably measure the same underlying concept of government legitimacy. As several recent studies find that questions regarding the confidence or competence of political institutions, such as the government, judiciary, parliament and police all measure the same concept, we believe that it is justifiable to mix questions in order to get an uninterrupted series. $^{8}$

In the absence of a long series of specific questions on the performance of or confidence in government institutions - these data are only available on a regular, annual basis from the mid-1990s - we therefore combine the long series of answers to the question "On the whole, are you very satisfied, fairly satisfied, not very satisfied or not at all satisfied with the way democracy works in (your country)?”, which was available until 2004, with answers to questions on how much confidence respondents have in either the parliament or the political parties; all questions are asked on a four-point scale. The question of confidence in parliament is available from 1994 and that of political parties from 1997. The overlap in coverage allows us to estimate the association between the first and the two latter questions. As the explanatory power of such estimates is very high, we eventually arrived at calculating the missing values by means this formula ${ }^{9}$ :

Imputed satisfaction with the way democracy works $=1.67 *$ confidence in parliament + $0.87 *$ confidence in parties +1.57

Fig. 1 shows the association between the satisfaction scores and the imputed scores, with an $\mathrm{R}$ squared of 0.8 . In case none of the questions are available for a year, the observation is missing.

\footnotetext{
${ }^{8}$ Bjørnskov and Sønderskov (2013) show that both in individual- and macro-level tests, confidence measures of political institutions tend to measure the same concept.

${ }^{9}$ The imputation formula derives from a set of OLS regressions using the observations from the mid-1990s in which both questions about confidence in specific institutions and the question of satisfaction with democracy were asked. A specification with a constant term, confidence in parliament and confidence in parties yielded the clearly best fit. We then used the constant and coefficients from this regression reported in (1) to impute comparable scores for the period from the mid-1990s to 2011.
} 


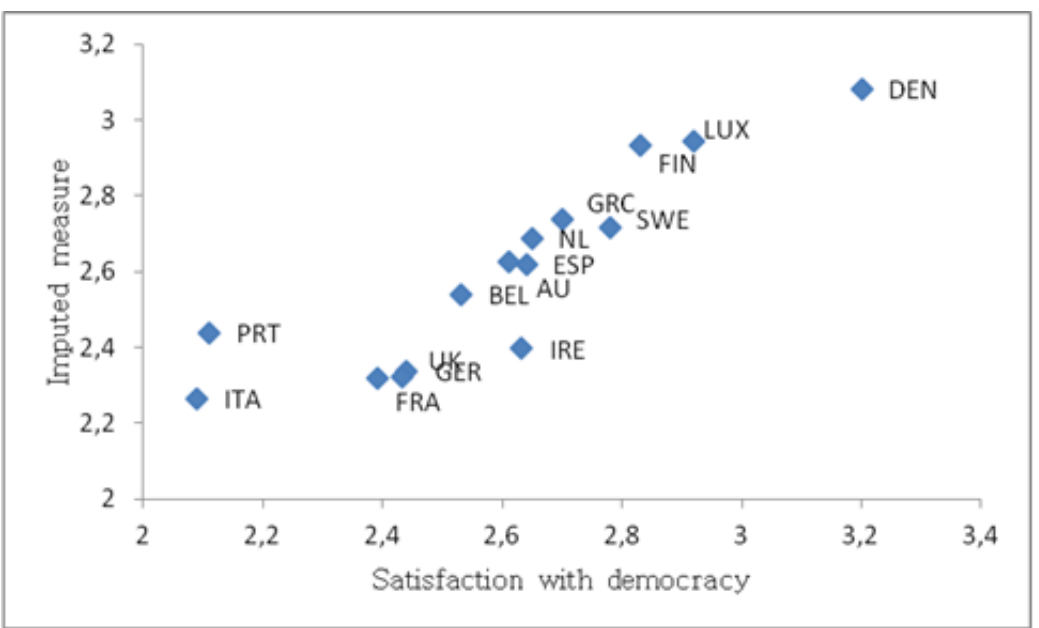

Fig. 1 Imputed legitimacy scores

\subsection{Main data}

We draw additional data from a number of sources. First, our main data on purchasing-power adjusted GDP per capita (in 2005 US dollars), openness to trade (trade volumes as percent of GDP), investment rates (percent of GDP) and the relative price of investment goods (capital goods prices as a ratio of the full price index) derive from the Penn World Tables, Mark 7.1 (Heston et al. 2012). We add a dummy for election years in order to control for political business cycle effects (Nordhaus 1975). Finally, we measure government size in two different ways. We either measure it as total government consumption as a percent of GDP or as total tax revenue as a percent of GDP, both drawn from OECD (2013) and WDI (2013). In subsequent tests, we add two components of the Economic Freedom of the World index: a measure of the quality of the legal system and a measure capturing the degree of regulatory freedom. Both are from Gwartney et al. (2012) and for both, we impute values within fiveyear intervals as the data are only available as annual scores after $2000 .{ }^{10}$ All data are summarized in Table 2.

\footnotetext{
${ }^{10}$ Basic institutional measures are sufficiently stable over time that imputation is unlikely to imply major imprecision (Sobel and Coyne 2011). We therefore follow Nyström (2009) in linearly interpolating values between five-year points.
} 
Table 2 Descriptive statistics

\begin{tabular}{lccccc}
\hline Name & Mean & $\begin{array}{c}\text { Std. } \\
\text { deviation }\end{array}$ & Min. & Max. & Observations \\
\hline Growth rate & .023 & .034 & -.167 & .113 & 573 \\
Legitimacy & 2.397 & .335 & 1.618 & 3.287 & 573 \\
Log initial GDP pc & 10.038 & .408 & 8.837 & 11.293 & 573 \\
Openness & 93.228 & 50.655 & 32.414 & 319.553 & 573 \\
Relative investment price & .940 & .127 & .666 & 1.359 & 573 \\
Election year & .292 & .455 & 0 & 1 & 573 \\
Government consumption & .201 & .034 & .098 & .298 & 573 \\
Government legitimacy & 2.397 & .335 & 1.618 & 3.287 & 573 \\
Post-communist & .162 & .369 & 0 & 1 & 573 \\
Tax revenue & .357 & .083 & .114 & .541 & 570 \\
Legal quality & 7.579 & 1.197 & 3.873 & 9.625 & 568 \\
Regulatory freedom & 6.609 & .988 & 3.999 & 8.548 & 568 \\
\hline
\end{tabular}

Our particular choice of data also alleviates a main problem in the literature, that the causal relation between government consumption and economic growth is arguably bidirectional. Bergh and Henrekson (2011) make an ingenious argument: just as the use of government consumption might entail a downwards bias as the nominator becomes smaller during crises, the use of tax revenues instead should entail an upwards bias. The reason is that while government consumption mechanically becomes a larger (smaller) share of GDP during crises (upturns), tax revenues decrease (increase) as a share of GDP during crises (upturns). We therefore test the main assertion of the paper using both measures of the size of government.

\subsection{Empirical strategy}

A central problem in most panel applications is that the main data are often non-stationary. Even though we in the following include a full set of annual period fixed effects and country fixed effects, growth rates and development levels tend to be persistent. An additional problem of working with annual data is that short-run and medium-to-long-run effects may differ. In our particular case, expansionary fiscal policy may under some circumstances cause GDP to increase, yet permanently larger public expenditures are arguably bad for growth. Likewise, J-curve adaptation patterns following policy changes could yield very different short- and long-run effects.

We therefore employ an error-correction model (ECM) in order to estimate the joint growth effects of government size and legitimacy. The model, which we outline in (1), has the benefit of allowing us to estimate both short-run and long-run (equilibrium) effects of policy 
changes. As de Boef and Keele (2008) show, ECM has the additional advantage of being robust to stationarity problems and more robust than most other estimators to causality problems. In particular, any effects of growth on perceived legitimacy are likely to be of a short-run nature. They may therefore bias the short-run estimates, which we do not actually use for analytical purposes, while keeping the more interesting long-run estimates fairly unbiased.

In all regressions, $\Delta Y_{i, t}$, the growth rate of GDP per capita $Y$ in country $i$ at time $t$, is the outcome variable. $\mathrm{X}$ is a vector of control variables, $\mathrm{G}$ is government size, $\mathrm{L}$ is legitimacy, I is a set of country fixed effects, $T$ is a set of period dummies, and $\varepsilon$ is an error term assumed to be iid (subscripts i and thave been excluded for simplicity). Right-hand side variables denoted by a $\Delta$ are annual changes and the related coefficients (all with subscript 1 ) thus capture short-run relations.

$$
\begin{aligned}
& \Delta \mathrm{Y}_{\mathrm{i}, \mathrm{t}}=\alpha_{0}+\alpha_{1} \ln \mathrm{Y}_{\mathrm{i}, \mathrm{t}-1}+\alpha_{2} \Delta \mathrm{Y}_{\mathrm{i}, \mathrm{t}-1}+\beta_{0} \mathrm{X}+\beta_{1} \Delta \mathrm{X}+\gamma_{0} \mathrm{G}+\gamma_{1} \Delta \mathrm{G}+\lambda_{0} \mathrm{~L}+\lambda_{1} \Delta \mathrm{L}+\delta_{0} \mathrm{G} \mathrm{L}+ \\
& \delta_{1} \Delta \mathrm{G} \Delta+\eta \mathrm{I}_{\mathrm{t}}+v_{\mathrm{i}} \mathrm{T}+\varepsilon
\end{aligned}
$$

We focus on the long-run effects of government size and legitimacy and their interaction, especially the latter, which indicates how legitimacy affects the growth effects of government size. The marginal long-run effect of an increase in government size is given by $\gamma_{0}+\delta_{0} \mathrm{~L}$; likewise, a change to legitimacy must be evaluated as $\lambda_{0}+\delta_{0} \mathrm{G}$ (cf. Brambor et al. 2006). ${ }^{11}$ We therefore both provide marginal effects at the $25^{\text {th }}$ percentile, the sample median and the $75^{\text {th }}$ percentile, and follow recent practice in plotting the full array of conditional marginal effects including 95 percent confidence intervals.

Finally, assuming no long-run J-curve adaption problems - the ECM approach captures short-run adaptation patterns in short-run effects - a "true" long-run effect can be calculated with ECM, as the specification includes a lagged level. ${ }^{12}$ The long-run multiplier of, e.g., a change to legitimacy is then given by $\lambda_{0} / \alpha_{1}$. With this additional interpretational caveat, we proceed to the results.

\footnotetext{
${ }^{11}$ Similarly, short-run effects are calculated as $\gamma_{1}+\delta_{1} L$ and $\lambda_{1}+\delta_{1} G$, respectively. Yet, since we do not focus on such effects, we refrain from showing the relatively limited short-run estimates.

${ }^{12}$ More precisely, ECM can credibly separate short- and long-run effects if potential J-curve adaptions do not extend so long into the future that they dominate any true long-run effects. Given the speed with which countries adapt after crises, we believe this to be unlikely.
} 


\section{Results}

We present our main results in Table 3a, which in columns 1 and 2 include all 30 countries and in columns 3 and 4 exclude all post-communist countries and therefore include only 18 countries. Table $3 \mathrm{~b}$ reports the marginal effects of government size and legitimacy, evaluated at three levels of the moderating variable. The letter $\mathrm{D}$ refers to annual changes (denoted $\Delta$ in equation 1), while L refers to lagged levels; D openness is thus the year-to-year change in trade volumes while L openness is the level around which such short-run changes occur. In all cases, we find a set of standard results. First, lagged growth is strongly significant with a coefficient around 0.3 to 0.4, indicating the well-known persistence of growth. Second, we also find strong evidence of convergence, as lagged GDP per capita is significant. Third, we observe a strong positive effect of openness to trade in the long run (L Openness) but not significantly so in the short run (D Openness). Finally, we find no evidence of growth consequences of political business cycles and only weak evidence of effects of relative investment prices, as these are only significant in the full sample in the short run. 
Table 3a Main results for growth

\begin{tabular}{|c|c|c|c|c|}
\hline Sample & $\begin{array}{l}\text { Growth } \\
\text { All } \\
1\end{array}$ & $\begin{array}{l}\text { Growth } \\
\text { All } \\
2\end{array}$ & $\begin{array}{c}\text { Growth } \\
\text { No post- } \\
\text { communist } \\
3\end{array}$ & $\begin{array}{c}\text { Growth } \\
\text { No post- } \\
\text { communist } \\
4\end{array}$ \\
\hline Log initial GDP & $\begin{array}{c}-.076^{* * *} \\
(.013)\end{array}$ & $\begin{array}{c}-.079 * * * \\
(.013)\end{array}$ & $\begin{array}{c}-.057 * * * \\
(.012)\end{array}$ & $\begin{array}{c}-.058^{* * *} \\
(.012)\end{array}$ \\
\hline L Growth & $\begin{array}{c}.302 * * * \\
(.046)\end{array}$ & $\begin{array}{l}.325 * * * \\
(.045)\end{array}$ & $\begin{array}{l}.348^{* * *} \\
(.052)\end{array}$ & $\begin{array}{c}.391^{* * *} \\
(.048)\end{array}$ \\
\hline L Openness & $\begin{array}{c}.035 * * * \\
(.009)\end{array}$ & $\begin{array}{c}.039 * * * \\
(.008)\end{array}$ & $\begin{array}{l}.021^{* *} \\
(.008)\end{array}$ & $\begin{array}{c}.025^{* * * *} \\
(.008)\end{array}$ \\
\hline D Openness & $\begin{array}{l}.023 \\
(.018)\end{array}$ & $\begin{array}{c}.025 \\
(.017)\end{array}$ & $\begin{array}{l}.035^{*} \\
(.020)\end{array}$ & $\begin{array}{l}.035^{*} \\
(.019)\end{array}$ \\
\hline L Rel. inv. price & $\begin{array}{l}-.028 \\
(.023)\end{array}$ & $\begin{array}{l}-.023 \\
(.021)\end{array}$ & $\begin{array}{l}-.010 \\
(.024)\end{array}$ & $\begin{array}{l}.003 \\
(.021)\end{array}$ \\
\hline D Rel. inv. price & $\begin{array}{c}.103 * * * \\
(.039)\end{array}$ & $\begin{array}{l}.093 * * \\
(.039)\end{array}$ & $\begin{array}{c}.029 \\
(.048)\end{array}$ & $\begin{array}{c}.025 \\
(.048)\end{array}$ \\
\hline L election year & $\begin{array}{l}.002 \\
(.002)\end{array}$ & $\begin{array}{c}.002 \\
(.002)\end{array}$ & $\begin{array}{c}.001 \\
(.002)\end{array}$ & $\begin{array}{c}.001 \\
(.002)\end{array}$ \\
\hline $\begin{array}{l}\text { L Government } \\
\text { consumption } \\
\text { D Government } \\
\text { consumption }\end{array}$ & $\begin{array}{l}.244 \\
(.248) \\
-.158 \\
(.148)\end{array}$ & & $\begin{array}{l}.242 \\
(.229) \\
.159 \\
(.164)\end{array}$ & \\
\hline $\mathrm{L}$ Tax revenue & & $\begin{array}{c}.304 * * * \\
(.114)\end{array}$ & & $\begin{array}{l}.217^{* *} \\
(.106)\end{array}$ \\
\hline D Tax revenue & & $\begin{array}{c}.239 * * * \\
(.072)\end{array}$ & & $\begin{array}{c}.261^{* * * *} \\
(.068)\end{array}$ \\
\hline L Legitimacy & $\begin{array}{l}.049 * * \\
(.023)\end{array}$ & $\begin{array}{c}.077 * * * \\
(.020)\end{array}$ & $\begin{array}{l}.052 \\
(.022)\end{array}$ & $\begin{array}{c}.058^{* * *} \\
(.019)\end{array}$ \\
\hline D Legitimacy & $\begin{array}{l}.005 \\
(.007)\end{array}$ & $\begin{array}{c}.004 \\
(.007)\end{array}$ & $\begin{array}{r}.004 \\
(.007)\end{array}$ & $\begin{array}{r}.004 \\
(.006)\end{array}$ \\
\hline $\begin{array}{l}\text { L Consumption * } \\
\text { legitimacy } \\
\text { D Consumption * } \\
\text { legitimacy }\end{array}$ & $\begin{array}{l}-.161 \\
(.099) \\
-.379 \\
(.740)\end{array}$ & & & \\
\hline $\begin{array}{l}\mathrm{L} \text { Tax * } \\
\text { legitimacy } \\
\mathrm{D} \text { Tax * } \\
\text { legitimacy }\end{array}$ & & $\begin{array}{c}-.159 * * * \\
(.047) \\
.723 * \\
(.372)\end{array}$ & $\begin{array}{l}-.174 * \\
(.093) \\
-.269 \\
(.712)\end{array}$ & $\begin{array}{c}-.113^{* *} \\
(.044) \\
.551 \\
(.346)\end{array}$ \\
\hline $\begin{array}{l}\text { Observations } \\
\text { R squared } \\
\text { between }\end{array}$ & $\begin{array}{l}515 \\
.249\end{array}$ & $\begin{array}{l}512 \\
.235\end{array}$ & $\begin{array}{l}434 \\
.223\end{array}$ & $\begin{array}{l}434 \\
.201\end{array}$ \\
\hline $\begin{array}{l}\text { R squared within } \\
\text { F statistic }\end{array}$ & $\begin{array}{r}.725 \\
25.72\end{array}$ & $\begin{array}{r}.735 \\
26.89\end{array}$ & $\begin{array}{l}.699 \\
19.12\end{array}$ & $\begin{array}{c}.708 \\
20.00\end{array}$ \\
\hline
\end{tabular}

Note: $* * *(* *)[*]$ denote significance at $\mathrm{p}<.01(\mathrm{p}<.05)[\mathrm{p}<.10]$. All regressions include fixed country and year effects. The full samples in columns 1 and 2 include 30 countries; the reduced samples in columns 3 and 4 include 18 countries. Variables denoted D are annual changes, variables denoted L are lagged levels. 
Table 3b Conditional marginal growth effects

\begin{tabular}{lcccc}
\hline Sample & $\begin{array}{c}\text { Growth } \\
\text { All }\end{array}$ & $\begin{array}{c}\text { Growth } \\
\text { All }\end{array}$ & $\begin{array}{c}\text { Growth } \\
\text { No post- } \\
\text { communist } \\
\text { 25th percentile }\end{array}$ & \multicolumn{3}{c}{$\begin{array}{c}\text { Growth } \\
\text { No post- } \\
\text { communist } \\
\text { Median }\end{array}$} & -.104 & Government spending / Tax revenue evaluated at & 4 \\
\hline 75th percentile & $(.087)$ & -.039 & -.134 & -.027 \\
& $-.143^{*}$ & $(.039)$ & $(.088)$ & $(.036)$ \\
25th percentile & $(.086)$ & $-.077^{*}$ & $-.176^{* *}$ & -.055 \\
& $-.197^{* *}$ & $(.039)$ & $(.088)$ & $(.036)$ \\
Median & $(.090)$ & $-.113^{* * *}$ & $-.215^{* *}$ & $-.079^{* *}$ \\
& $.022^{* * *}$ & $(.043)$ & $(.093)$ & $(.039)$ \\
75th percentile & $(.008)$ & $.032^{* * *}$ & $.023^{* * *}$ & $.026^{* * *}$ \\
& $.018^{* * *}$ & $(.008)$ & $(.008)$ & $(.007)$ \\
& $(.006)$ & $.020^{* * *}$ & $.019^{* * *}$ & $.018^{* * *}$ \\
& $.014^{* * *}$ & $(.005)$ & $(.006)$ & $(.005)$ \\
& $(.005)$ & $.011^{* *}$ & $.014^{* * *}$ & $.011^{* *}$ \\
& $(.005)$ & $(.005)$ & $(.004)$ \\
\hline
\end{tabular}

Note: ${ }^{* * *}(* *)[*]$ denote significance at $\mathrm{p}<.01(\mathrm{p}<.05)[\mathrm{p}<.10]$. All regressions include fixed country and year effects. The full samples in columns 1 and 2 include 30 countries; the reduced samples in columns 3 and 4 include 18 countries.

Turning to the main purpose of this paper, we find that government size only affects growth unambiguously in the long run. The short-run association, on the one hand, is unclear. When measured as government consumption, which we argue above implies a downwards endogeneity bias, we find that it tends to be negatively associated with growth and that the negative association increases with legitimacy. When measured as tax revenue, which entails an upwards endogeneity bias, we find a significantly positive association that increases with legitimacy. As the true short-run effect of changing government size must be bounded by these two estimated associations, we cannot make any statements with any reasonable precision.

In the long run, on the other hand, government size, both as measured by government consumption and by tax revenue, is on average negatively associated with economic growth. As we report in Table $3 b$ and depict in Figs. 2a and 2b, which show the marginal effects of government size conditional on legitimacy, we find an average negative association that is significant from a level of legitimacy of approximately 2.4, which is slightly below the median reported in Table 3b. While the point estimate of government size as reported in Table 3a appears positive, with an interaction term the simple estimate is evaluated at a value of legitimacy of 0 , which we do not observe in the data. Instead, the point estimate must be evaluated as, in this case, $0.244-0.161 *$ L Legitimacy, which is the estimate depicted in Figs. $2 \mathrm{a}$ and $2 \mathrm{~b}$. In other words, we find that government size is more detrimental to long-run 
economic performance the more positively the population evaluates the legitimacy of the government and the political institutions. Although there is more variation among the postcommunist countries that we observe at the end of their transition towards market economy and democracy, this finding also holds when we exclude those countries in columns 3 and 4 . As such, we seem to identify a general phenomenon among our set of European countries. A set of jackknife tests (not shown) in which we exclude each of the 30 countries, one at a time, also corroborates that the main findings generalizes to most countries.

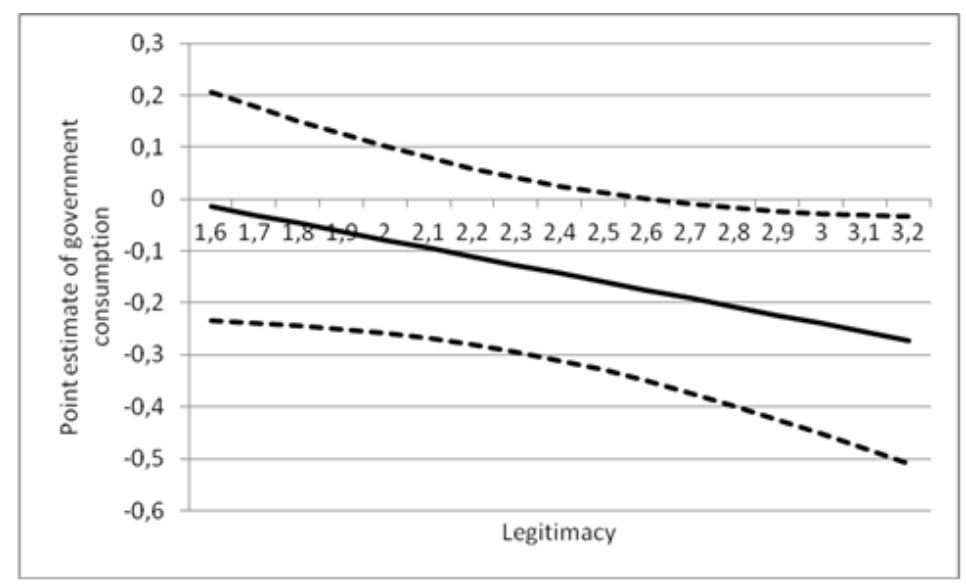

Fig. 2a Heterogeneous growth effects of government consumption, all countries

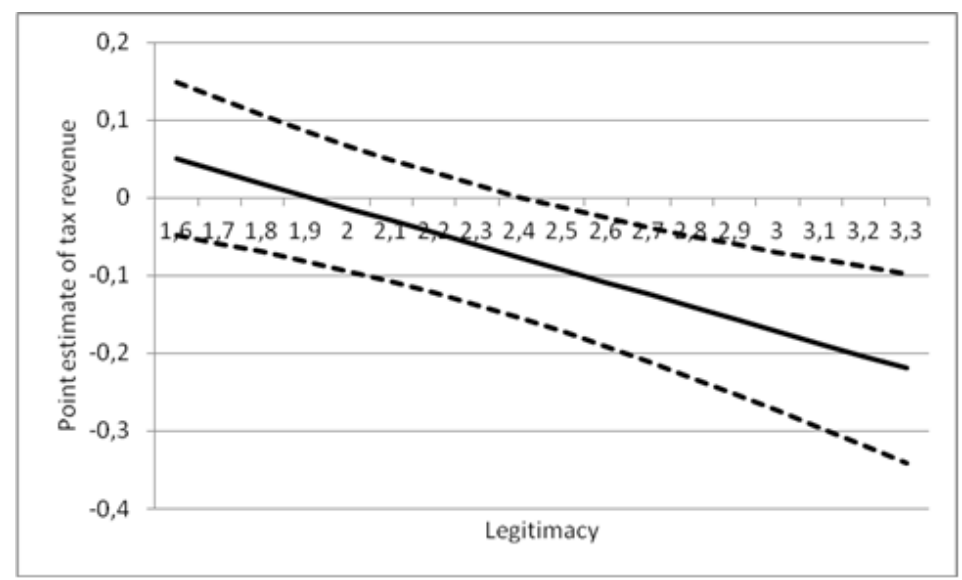

Fig. 2b Heterogeneous growth effects of tax revenue, all countries

Turning the association around and interpreting the findings symmetrically, as recommended by Brambor et al. (2006), we find that legitimacy per se is beneficial for growth whenever government size does not exceed a particular level. This is in line with the theoretical reasoning at the end of Section 2.1, to the effect that high legitimacy might reflect quality of implementation. As such, it can reinforce a positive growth effect of government 
size of government policies (and reinforce a negative growth effect if government is large and if its policies have a negative marginal growth impact). Figs. 3a and 3b depict this relation, conditional on the size of government. For government final consumption (which, it should be pointed out, does not include transfers and subsidies), the cut-off at which legitimacy loses significance occurs at approximately 25\% of GDP; for tax revenues, the cut-off is approximately 43\% of GDP. In recent years, the group of countries that exceeds these limits includes France and the three Nordic welfare states of Denmark, Finland and Sweden. As with the effects of government size, the marginal effects of legitimacy are also broadly robust to a jackknife exercise.

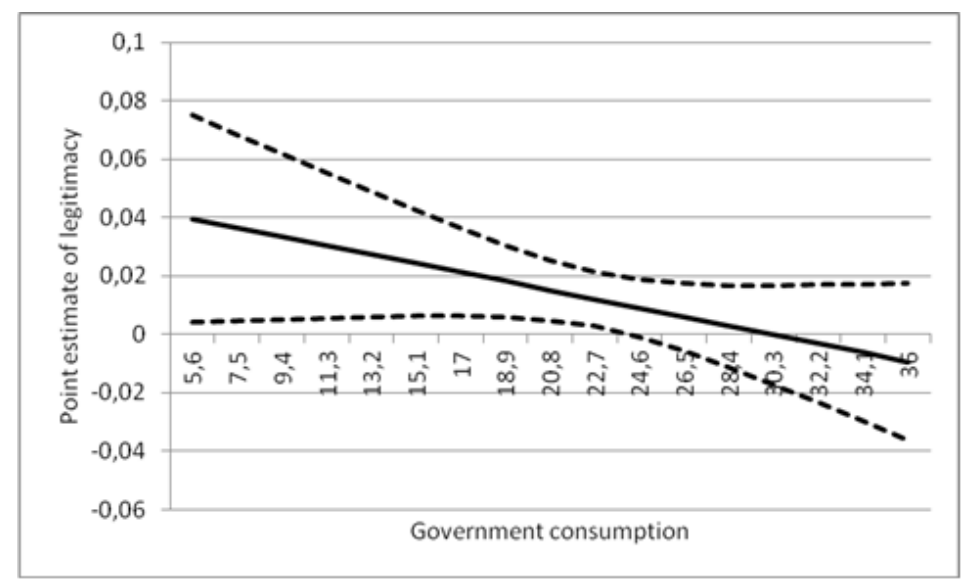

Fig. 3a Heterogeneous growth effects of legitimacy given consumption, all countries

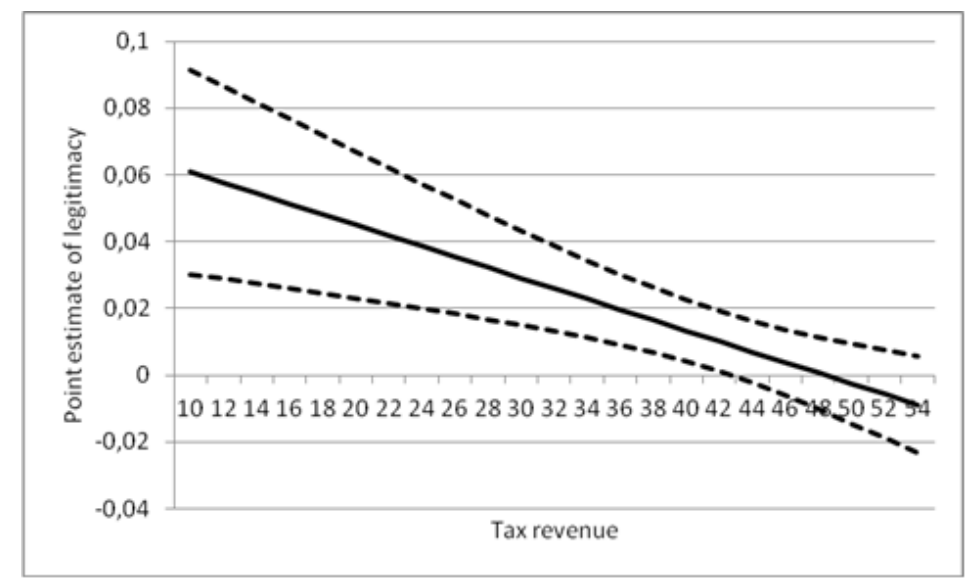

Fig. 3b Heterogeneous growth effects of legitimacy given taxes, all countries

However, before being able to conclude, we need to ensure that our findings on the effects of legitimacy on how government size affects growth are not merely driven by 
differences in institutional quality. ${ }^{13}$ Voters' perceptions of the legitimacy of political actors and institutions are arguably increasing in their actual performance, although theories of rational ignorance imply that de facto performance may only be weakly associated with perceptions. In general one would expect to find, in countries with objectively better judicial institutions, high-quality bureaucracies and relatively non-intrusive market regulations, more positive evaluations of legitimacy (Blind 2006).

This poses a problem in the present context, as the quality of economic-judicial institutions has emerged as one of the strongest determinants of economic growth and longrun economic performance (Rodrik et al. 2004; Acemoglu and Johnson 2005; Bjørnskov and Méon 2013; Flachaire et al. 2014). If the interaction between legitimacy, as measured in this paper, and government size merely captures relevant elements of formal, objective institutions, our empirical tests are not likely to inform about which theoretical considerations are consistent with the evidence or what implications one can draw from them. In Table 4, we therefore add measures of the quality of the legal system and regulatory freedom to our specification.

\footnotetext{
${ }^{13}$ We have ensured that our main findings do not change when using a fixed effects estimator in levels (results available upon request). The main difference is that the choice of applying an ECM reduces the amount of noise due to short-term effects, rendering the long-run effects more precisely estimated.
} 
Table 4 Main results for growth

\begin{tabular}{|c|c|c|c|c|}
\hline Sample & $\begin{array}{c}\text { Growth } \\
\text { All } \\
1\end{array}$ & $\begin{array}{l}\text { Growth } \\
\text { All } \\
2\end{array}$ & $\begin{array}{c}\text { Growth } \\
\text { All } \\
3\end{array}$ & $\begin{array}{c}\text { Growth } \\
\text { All } \\
4\end{array}$ \\
\hline Log initial GDP & $\begin{array}{c}-.076 * * * \\
(.013)\end{array}$ & $\begin{array}{c}-.077 * * * \\
(.013)\end{array}$ & $\begin{array}{c}.079 * * * \\
(.013)\end{array}$ & $\begin{array}{c}-.081 * * * \\
(.013)\end{array}$ \\
\hline L Growth & $\begin{array}{c}.302 * * * \\
(.046)\end{array}$ & $\begin{array}{l}.293^{* * * *} \\
(.047)\end{array}$ & $\begin{array}{l}.325^{* * *} \\
(.045)\end{array}$ & $\begin{array}{l}.309 * * * \\
(.045)\end{array}$ \\
\hline L Openness & $\begin{array}{c}.035^{* * *} \\
(.009)\end{array}$ & $\begin{array}{l}.029 * * * \\
(.009)\end{array}$ & $\begin{array}{c}.039 * * * \\
(.008)\end{array}$ & $\begin{array}{c}.034^{* * *} \\
(.009)\end{array}$ \\
\hline D Openness & $\begin{array}{l}.023 \\
(.018)\end{array}$ & $\begin{array}{r}.023 \\
(.018)\end{array}$ & $\begin{array}{l}.025 \\
(.017)\end{array}$ & $\begin{array}{l}.029 \\
(.018)\end{array}$ \\
\hline L Rel. inv. price & $\begin{array}{l}-.028 \\
(.023)\end{array}$ & $\begin{array}{l}-.027 \\
(.023)\end{array}$ & $\begin{array}{l}-.023 \\
(.021)\end{array}$ & $\begin{array}{l}-.022 \\
(.022)\end{array}$ \\
\hline D Rel. inv. price & $\begin{array}{c}.103^{* * *} \\
(.039)\end{array}$ & $\begin{array}{l}.105^{* * *} \\
(.040)\end{array}$ & $\begin{array}{l}.093 * * \\
(.039)\end{array}$ & $\begin{array}{l}.099 \\
(.039)\end{array}$ \\
\hline L election year & $\begin{array}{c}.002 \\
(.002)\end{array}$ & $\begin{array}{c}.002 \\
(.002)\end{array}$ & $\begin{array}{c}.002 \\
(.002)\end{array}$ & $\begin{array}{c}.002 \\
(.002)\end{array}$ \\
\hline $\begin{array}{l}\text { L Government } \\
\text { consumption } \\
\text { D Government } \\
\text { consumption }\end{array}$ & $\begin{array}{l}.244 \\
(.248) \\
-.158 \\
(.148)\end{array}$ & $\begin{array}{l}.289 \\
(.252) \\
-.169 \\
(.149)\end{array}$ & & \\
\hline L Tax revenue & & & $\begin{array}{c}.304 * * * \\
(.114)\end{array}$ & $\begin{array}{c}.348 * * * \\
(.117)\end{array}$ \\
\hline D Tax revenue & & & $\begin{array}{c}.239 * * * \\
(.072)\end{array}$ & $\begin{array}{c}.217 * * * \\
(.072)\end{array}$ \\
\hline L Legitimacy & $\begin{array}{l}.049 * * \\
(.023)\end{array}$ & $\begin{array}{r}.054 \\
(.024)\end{array}$ & $\begin{array}{c}.077 * * * \\
(.020)\end{array}$ & $\begin{array}{l}.084^{* * *} \\
(.021)\end{array}$ \\
\hline D Legitimacy & $\begin{array}{l}.005 \\
(.007)\end{array}$ & $\begin{array}{r}.002 \\
(.007)\end{array}$ & $\begin{array}{c}.004 \\
(.007)\end{array}$ & $\begin{array}{c}.002 \\
(.007)\end{array}$ \\
\hline $\begin{array}{l}\text { L Consumption * } \\
\text { legitimacy } \\
\text { D Consumption * } \\
\text { legitimacy }\end{array}$ & $\begin{array}{l}-.161 \\
(.099) \\
-.379 \\
(.740)\end{array}$ & $\begin{array}{l}-.177 * \\
(.101) \\
-.500 \\
(.741)\end{array}$ & & \\
\hline $\begin{array}{l}\mathrm{L} \text { Tax * } \\
\text { legitimacy }\end{array}$ & & & $\begin{array}{c}-.159 * * * \\
(.047)\end{array}$ & $\begin{array}{c}-.173 * * * \\
(.048)\end{array}$ \\
\hline $\begin{array}{l}\text { D Tax * } \\
\text { legitimacy }\end{array}$ & & & $\begin{array}{l}.723^{*} \\
(.372)\end{array}$ & $\begin{array}{c}.719 * \\
(.371)\end{array}$ \\
\hline L Legal quality & & $\begin{array}{l}-.002 \\
(.003)\end{array}$ & & $\begin{array}{l}-.002 \\
(.002)\end{array}$ \\
\hline D Legal quality & & $\begin{array}{l}.009 * * \\
(.004)\end{array}$ & & $\begin{array}{l}.009 * * \\
(.004)\end{array}$ \\
\hline $\begin{array}{l}\text { L Regulatory } \\
\text { freedom } \\
\text { D Regulatory } \\
\text { freedom } \\
\end{array}$ & & $\begin{array}{l}-.005 \\
(.003) \\
.007 \\
(.005) \\
\end{array}$ & & $\begin{array}{c}-.005 \\
(.003) \\
.007 \\
(.005) \\
\end{array}$ \\
\hline Observations & 515 & 511 & 512 & 510 \\
\hline R squared between & .249 & .259 & .235 & .255 \\
\hline R squared within & .725 & .729 & .735 & .738 \\
\hline F statistic & 25.72 & 23.87 & 26.89 & 24.81 \\
\hline
\end{tabular}

Note: $* * *(* *)[*]$ denote significance at $\mathrm{p}<.01(\mathrm{p}<.05)$ [p<.10]. All regressions include fixed country and year effects. The full samples in columns 1 and 3 include 30 countries, columns 2 and 4 include 29 countries, as Macedonia drops out due to missing institutional data. Variables denoted D are annual changes, variables denoted $\mathrm{L}$ are lagged levels. 
We report the main results from Table 3a in columns 1 and 3 for comparison, and add the formal institutional measures in columns 2 and 4 . While the stability of measures of legal quality, in particular, prevents us from identifying their true long-run effects with a fixed effects estimator - all long-run effects of stable, high-quality institutions will be captured by the country fixed effects and are thus not visible in the estimates - we find that improvements in legal quality are associated with short-run improvements. ${ }^{14}$ Conversely, we find no direct consequences of regulatory freedom. Most importantly, a direct comparison between columns 1 and 2, and between columns 3 and 4, reveal that our main estimates are only very weakly affected by the inclusion of additional variables. If anything, the inclusion of legal quality slightly amplifies the effects of government size and legitimacy. Our main findings are therefore robust to controlling for more objective measures of the quality of economic-judicial institutions, suggesting an independent effect of legitimacy.

\section{Concluding remarks}

The literature on how government size affects economic growth has come to indicate that, at least in developed countries, the influence is of a negative kind. Still, the relationship varies between countries, which suggests that other factors influence the magnitude of the long-run effect of government size. We hypothesize that government legitimacy has such an influence - that the attitudes of citizens towards the political system shape how government expenditures and taxes affect the growth-relevant behavior of both economic and political actors and, ultimately, growth.

We believe that there are different mechanisms through which legitimacy can have an influence on how government size affects long-run growth. On the one hand, legitimacy may imply that government decisions are easier and less costly to enforce, that tax evasion is limited when citizens tend to believe that government spends the revenue in legitimate ways and that more resources are therefore employed for productive purposes. On the other hand, voters who consider government legitimate may collect less information on actual policies

\footnotetext{
${ }^{14}$ We do not doubt that good legal institutions and strong protection of private property rights are positively associated with economic development in the long run. However, with our choice of estimation strategy across a group of relatively similar countries, we are technically unable to detect this influence.
} 
and remain ignorant of de facto policies and consequences, which enables governments to bias spending towards satisfying special interests and benefitting populist purposes. While the first type of mechanism may reduce the negative effects of government size and potentially turn them positive, the second type would imply that the negative growth effects of government size might increase with legitimacy.

We estimate net effects of the interaction of government size and legitimacy by employing an error-correction model with panel data (from 1975 onwards) and country and time fixed effects for up to 30 developed countries. This model enables us to estimate both short- and long-run effects of policy changes and alleviates a set of standard statistical problems.

Our most important finding is that government size is more negatively related to longrun growth the higher government legitimacy is. That is, the negative mechanisms identified in our theoretical discussion - the ones related to how policymakers make use of how legitimacy affects economic actors - dominate the positive ones. This result holds both for the sample as a whole and when removing post-communist countries; it is also robust to including measures of institutional quality. Moreover, we find that legitimacy in itself is beneficial for growth when government size is "small enough" (less than 25 percent in the case of government consumption and less than 43 percent in the case of taxes).

What conclusions can be drawn from these results? Since the negative effects of government consumption and tax revenues are increasing in legitimacy, while the positive effects of legitimacy are decreasing in government size, our results imply that the best constellation seems to be one in which government is limited but where government legitimacy is high. Conversely, constellations with large government and limited legitimacy or limited government and substantial legitimacy tend to produce similar, comparatively average results. So while some seem to assume that big government is beneficial as long as the electorate considers government legitimate, our findings suggest otherwise. In fact, a large government size with high legitimacy seems detrimental to growth, one implication of which is that is not necessarily desirable to pursue legitimacy regardless of the setting in which it exists. Our exercise illustrates the importance of not evaluating either government size or legitimacy in isolation: they interact in systematic ways.

So, should one worry about potential decreases in government legitimacy? Not necessarily. For example, in the early 1980s Denmark experienced a drop in government legitimacy, but this entailed a new government taking over and a substantial change of policy direction, with beneficial growth effects. Maybe Ireland at present is a similar example, where 
decreasing legitimacy has been a force inducing politicians to undertake economic reforms. Conversely, an increase in legitimacy can be worrisome - Italy is a case in point - if it leads to a reduced willingness on the part of politicians to undertake reform. There may of course be problems with decreases in legitimacy, but for the group of countries with big governments, our results at least lead us to think that the way such governments affect growth will improve.

\section{References}

Acemoglu, D., \& Johnson, S. (2005). Unbundling institutions. Journal of Political Economy, 113(5), 949-995.

Aghion, P., Algan, Y., Cahuc, P., \& Shleifer, A. (2010). Regulation and distrust. Quarterly Journal of Economics, 125(3), 1015-1049.

Aidt, T. (2003). Economic analysis of corruption: a survey. Economic Journal, 11(491), F632-F652.

Alfonso, A., \& Furceri, D. (2010). Government size, composition, volatility and economic growth. European Journal of Political Economy, 26(4), 517-532.

Beetham, D. (1993). In defence of legitimacy. Political Studies, 41(3), 488-491.

Bergh, A., \& Bjørnskov, C. (2011). Historical trust levels predict current welfare state size. Kyklos, 64(1), 1-19.

Bergh, A., \& Henrekson, M. (2011). Government size and growth: a survey and interpretation of the evidence. Journal of Economic Surveys, 25(5), 872-897.

Bergh, A., \& Karlsson, M. (2010). Government size and growth: accounting for economic freedom and globalization. Public Choice, 142(1), 195-213.

Bjørnskov, C., \& Méon, P.-G. (2013). Is trust the missing root of institutions, education, and development? Public Choice, 157(3-4), 641-669. 
Bjørnskov, C., \& Mannemar Sønderskov, K. (2013). Is social capital a good concept? Social Indicators Research, 114(3), 1225-1242.

Bleaney, M., Gemmell, N., \& Kneller, R. (2001). Testing the endogenous growth model: public expenditure, taxation, and growth over the long run. Canadian Journal of Economics, 34(1), 36-57.

Blind, P. K. (2006). Building trust in government in the twenty-first century: review of literature and emerging issues. Unpublished manuscript, UNDESA, New York.

Brambor, T., Roberts Clark, W., \& Golder, M. (2006). Understanding interaction models: improving empirical analyses. Political Analysis, 14(1), 63-82.

Buchanan, J. M. (1967). The fiscal illusion. In Public finance in democratic process (pp. 126-142). Chapel Hill: University of North Carolina Press.

Caplan, B. (2007). The myth of the rational voter. Princeton: Princeton University Press.

Caplan, B., \& Stringham, E. (2005). Mises, Bastiat, public opinion, and public choice. Review of Political Economy, 17(1), 79-105.

De Boef, S., \& Keele, L. (2008). Taking time seriously. American Journal of Political Science, 52(1), 184-200.

Colombatto, E. (2014). A theory of institutional resilience. In T. Eisenberg \& G. B. Ramello (Eds.), Research handbook on comparative law and economics (forthcoming). Cheltenham: Edward Elgar.

Downs, A. (1957). An economic theory of democracy. Cambridge: Cambridge University Press.

EuroBarometer (2013). Standard EuroBarometer, all editions 1973-2012. Online database, available at http://ec.europa.eu/public_opinion/index_en.htm.

Facchini, F., \& Melki, M. (2013). Efficient government size: France in the $20^{\text {th }}$ century. European Journal of Political Economy, 31(September), 1-14.

Fischer, J. A.V. (2011). Living under the "right” government: does political ideology matter to trust in political institutions? An analysis for OECD countries. MPRA working paper no. 33344, University of Munich. 
Flachaire, E., García-Peñalosa, C., \& Konte, M. (2014). Political versus economic institutions in the growth process. Journal of Comparative Economics, 42(1), 212-229.

Gilley, B. (2006). The determinants of state legitimacy: results for 72 countries. International Political Science Review, 27(1), 47-71.

Halla, M., \& Schneider, F. G. (2014). Taxes and benefits: two options to cheat on the state. Oxford Bulletin of Economics and Statistics, 76(3), 411-431.

Heston, A., Summers, R., \& Aten, B. (2012). Penn world tables version 7.1. Center for International Comparisons of Production, Income and Prices at the University of Pennsylvania, November.

King, R. G., \& Rebelo, S. (1990). Public policy and economic growth: developing neoclassical implications. Journal of Political Economy, 98(5), S126-S150.

Kneller, R., Bleaney, M. F., \& Gemmell, N. (1999). Fiscal policy and growth: evidence from OECD countries. Journal of Public Economics, 74(2), 171-190.

Levi, M., \& Sacks, A. (2009). Legitimating beliefs: sources and indicators. Regulation \& Governance, 3(4), 311-333.

Levi, M., Sacks, A., \& Tyler, T. R. (2009). Conceptualizing legitimacy, measuring legitimating beliefs. American Behavioral Scientist, 53(3), 354-375.

Lieberman, E. S. (2002). Taxation data as indicators of state-society relations: possibilities and pitfalls in cross-national research. Studies in Comparative International Development, 36(4), 89-115.

Lipset, S. M. (1959). Some social requisites of democracy: economic development and political legitimacy. American Political Science Review, 53(1), 69-105.

Mendoza, E. G., Milesi-Feretti, G. M., \& Asea, P. (1997). On the ineffectiveness of tax policy in altering long-run growth: Harberger's superneutrality conjecture. Journal of Public Economics, 66(1), 99-126.

Murphy, K. M., Shleifer, A., \& Vishny, R. W. (1993). Why is rent-seeking so costly to growth? American Economic Review, 83(2), 409-414. 
Nijkamp, P., \& Pot, J. (2004). Meta-analysis of the effect of fiscal policies on long-run growth. European Journal of Political Economy, 20(1), 91-124.

Nannestad, P., \& Paldam, M. (1994). From the pocketbook of the welfare man: a pooled cross-section study of economic voting in Denmark, 1986-92. British Journal of Political Science, 27(1), 119-136.

Nordhaus, W. (1975). The political business cycle. Review of Economic Studies, 42(2), 169-190.

Nyström, K. (2008). The institutions of economic freedom and entrepreneurship: evidence from panel data. Public Choice, 136(3-4), 269-282.

OECD (2013). OECD tax statistics. Database. Online database available at DOI: 10.1787/tax-data-en.

Oto-Peralías, D., \& Romero-Ávila, D. (2013). Tracing the link between government size and growth: the role of public sector quality. Kyklos, 66(2), 229-255.

Pinotti, P. (2012). Trust, regulation and market failures. Review of Economics and Statistics, 94(3), 650-658.

Pitlik, H., \& Kouba, L. (2014). Does social distrust always lead to a stronger support for government intervention? Policy paper no. 8, WWWforEurope, European Commission, Brussels.

Richardson, G. (2008). The relationship between culture and tax evasion across countries: additional evidence and extensions. Journal of International Accounting, Auditing and Taxation, 17(2), 67-78.

Rodrik, D., Subramanian, A., \& Trebbi, F. (2004). Institutions rule: the primacy of institutions over geography and integration in economic development. Journal of Economic Growth, 9(2), 131-165.

Romero-Ávila, D., \& Strauch, R. (2008). Public finances and long-term growth in Europe: evidence from a panel data analysis. European Journal of Political Economy, 24(1), 172-191.

Rudolph, T. J. (2009). Political trust, ideology, and public support for tax cuts. Public Opinion Quarterly, 73(1), 144-158.

Rudolph, T. J., \& Evans, J. (2005). Political trust, ideology, and public support for government spending. American Journal of Political Science, 49(3), 660-671. 
Seligson, M. A. (2002). The impact of corruption on regime legitimacy: a comparative study of four Latin American countries. Journal of Politics, 64(2), 408-433.

Sobel, R. S., \& Coyne, C. J. (2011). Cointegrating institutions: the time series properties of country institutional measures. Journal of Law and Economics, 54(1), 111-134.

Tyler, T. R. (2006a). Psychological perspectives on legitimacy and legitimation. Annual Review of Psychology, 57, 357-400.

Tyler, T. R. (2006b). Why people obey the law. Princeton: Princeton Univeristy Press.

Weede, E. (1996). Legitimacy, democracy and comparative economic growth reconsidered. European Sociological Review, 12(3), 217-225.

Yamamura, E. (2012). Trust in government and its effect on preferences for income redistribution and perceived tax burden. MPRA working paper no. 39833, University of Munich. 